\title{
YOUTUBE, CONTENT ID A TVORBA UŽIVATELŮ VE SVĚTLE ČLÁNKU 17 DSM SMĚRNICE
}

\author{
JELIZAVETA LAŠKEVIČOVÁ ${ }^{1}$
}

\begin{abstract}
ABSTRAKT
Příspěvek na př́kladu YouTube jako typické upload-platformy zkoumá dvě cesty nabízené článkem 17 DSM směrnice, jak zachovat soulad sdîlení uživatelského obsahu s právem duševního vlastnictví za podmínek nového režimu odpovědnosti upload-platforem. Jedno z nabízených východisek $v$ důsledku vede k zavedení systémů automatizovaného rozpoznávání obsahu. Nástroj Content ID vyvinutý YouTube má předpoklady stát se určujícím pro stanovení standardu, který musí takové systémy splňovat. Proto lze na jeho př́kladu hodnotit, zda je cesta filtrování obsahu vhodná pro spravedlivé vyvážení rozličných zájmů zúčastněných subjektů. $V$ př́spěvku bude seznáno, že nástroje automatického rozpoznávání obsahu jsou problematické, a bude diskutována německá cesta implementace, která kreativně využívá druhou možnost, tedy získání svolení nositelů práv, pro zavedení nové výjimky. Závěrem bude nastíněn význam německé výjimky pro budoucí efektivní licencování děl za podmínek odstavců 1 a 2 článku 17 DSM směrnice formou zákonné licence.
\end{abstract}

\section{KLÍČOVÁ SLOVA}

článek 17 DSM směrnice, YouTube, Content ID, UGC, výjimky a omezení, filtrování obsahu, licencování

Jelizaveta Laškevičová, studentkou pátého ročníku Právnické fakulty Univerzity Karlovy. Kontaktní e-mail: liz.lashkevich@gmail.com. 


\begin{abstract}
The article, using the example of YouTube as a typical upload platform, examines the two ways offered by Article 17 of the DSM Directive on how to keep the sharing of user-generated content in line with intellectual property rights under the new upload platform liability regime. One of the offered solutions leads to the introduction of automated content recognition systems. The Content ID system developed by YouTube has the capacity to become a standard for such systems. Therefore, its example can be used to assess whether a content-filtering path is appropriate for striking a fair balance of the different interests of stakeholders. The paper will recognize that automatic content recognition tools are problematic, and will discuss the German path of implementation, which creatively uses the second option, i.e. obtaining the consent of rights holders, to introduce a new exception. The article ends with a discussion of the importance of the German exception to the future effective licensing of protected works under the conditions of paragraphs 1 and 2 of Article 17 of the DSM Directive, which could take form of a statutory licence.
\end{abstract}

\title{
KEYWORDS
}

article 17 DSM Directive, YouTube, Content ID, UGC, exceptions and limitations, upload filters, licensing

\section{1. ÚVOD}

Článek 17 DSM směrnice ${ }^{2}$ přináší výrazné změny pro tzv. upload-platformy, které stojí na pomezí mezi klasickými poskytovateli hostingových služeb požívajícími safe harbour a poskytovateli on-demand služeb, kteří plně odpovídají za jimi zpřístupňovaný obsah. Upload-platformy jsou zásadním prvkem participativního webu, protože vytvářejí prostředí pro tvorbu nového obsahu a sociální interakce. Typickým představitelem těchto platforem je YouTube. Vzhledem k množství nahrávaného obsahu (v březnu 2019 bylo každou minutu na YouTube nahráváno cca 500 hodin videa) ${ }^{3}$ a množství odběratelů (mezi lety 2018 a 2019 narostl počet kanálů na YouTube,

2 Směrnice (EU) 2017/790 o autorském právu a právech s ním souvisejících na jednotném digitálním trhu a o změně směrnic 96/9/ES a 2001/29/ES. 
které mají více než 1 milion odběratelů, o $50 \%)^{4}$ jde o platformu, která je pro fungování participativního webu velmi podstatná.

YouTube, který původně nabízel téměř výlučně uživatelský obsah, se díky povaze svých služeb potýkal se značnými problémy $\mathrm{v}$ oblasti porušování autorského práva. ${ }^{5} \mathrm{~V}$ reakci na konflikty s nositeli práv začal YouTube vyvijet systém automatizovaného rozpoznávání obsahu Content ID, jehož prostřednictvím nyní probíhá $98 \%$ správy autorských práv na YouTube. ${ }^{6}$

Článek 17 DSM směrnice zakotvuje nový režim odpovědnosti uploadplatforem a nabízí dvě východiska, jak zachovat soulad sdílení uživatelského obsahu s právem duševního vlastnictví. Implementací můžou národní zákonodárci podpořit jedno z těchto řešení na úkor druhého a tak ovlivnit, kterou cestu bude praxe spíš využívat. Jedno z nabízených východisek $\mathrm{v}$ důsledku vede $\mathrm{k}$ zavedení systémů automatizovaného rozpoznávání obsahu, jak bude demonstrováno níže. Proto lze na př́kladu Content ID jako typického zástupce těchto systémů zkoumat, zda je tato cesta vhodná zejména $\mathrm{z}$ hlediska ochrany práv uživatelů. $\mathrm{V}$ příspěvku bude seznáno, že nástroje automatického rozpoznávání obsahu jsou problematické, a bude diskutována německá cesta implementace, která kreativně využívá druhou možnost, tedy získání svolení nositelů práv, pro zavedení nové výjimky. Závěrem bude nastíněn význam německé výjimky pro budoucí efektivní licencování děl za podmínek odstavců 1 a 2 článku 17 DSM směrnice formou zákonné licence.

3 JOHNSON, Eric. Full Q\&A: YouTube CEO Susan Wojcicki talks about child safety, the Google walkout, and AI on Recode Decode [online]. 2019 [cit. 27.09.2020]. Dostupné z: https://www.vox.com/podcasts/2019/3/11/18259303/youtube-susan-wojcicki-childcomments-videos-google-walkout-kara-swisher-decode-podcast-interview

4 Öffentliche Konsultation zur Umsetzung der EU-Richtlinie imUrheberrecht (DSM-RL (EU) 2019/790) [online]. Google a YouTube, 2019. s. 17. [cit. 23.09.2020]. Dostupné z: https://www.bmjv.de/SharedDocs/Gesetzgebungsverfahren/DE/Konsultation_Umsetzung_EU_Richtlinien_Urheberrecht.html?nn $=6712350$

5 BURGESS, Jean a Joshua GREEN. YouTube: Online Video and Participatory Culture. Polity Press, 2018. s. 35.

6 How Google Fights Piracy [online]. 2018. s. 13. [cit. 24.09.2020]. Dostupné z: https:// www.blog.google/documents/27/How_Google_Fights_Piracy_2018.pdf 


\section{CHARAKTERISTIKA UŽIVATELSKÉ TVORBY}

V posledních letech zaznamenala kreativita uživatelů na upload-platformách nevídaný rozmach. Důvodem je dostupnost velkého množství děl, ze kterých mohou uživatelé čerpat, v digitální podobě, dále také rozvoj nástrojů, pomocí kterých je obsah vytvářen, a rozšířenost širokopásmového internetu. ${ }^{7}$ OECD vnímá obsah vytvářený uživateli (user created content nebo user generated content, dále jen „UGC“) jako jeden ze základních prvků participativního webu a stanovuje tři vlastnosti, které jsou pro něj charakteristické - nutnost zpřístupnění veřejnosti (byt se může jednat o úžeji vymezenou veřejnost jako např. určitou komunitu), vynaložení tvưrčího úsilí (ačkoli míra kreativity se může u jednotlivých výtvorů velmi lišit) a vytvoření mimo profesní rámec (creation outside of professional routines and practices). ${ }^{8}$

Tvorba uživatelů může na sebe brát různé podoby, každopádně se často neobejde bez prvků, které jsou chráněny autorským právem. Někdy sledují výpůjčky uživatelů účely předvídané zákonnými výjimkami a omezeními autorského práva jako karikatura, parodie či recenze, jindy jde o transformativní užití jiného rázu, např. tzv. meme - existující dílo (typicky fotografie, obraz nebo video) kreativně pozměněné tak, aby vyvolávalo komický efekt, které se organicky šîrí na sociálních sítích. ${ }^{9}$ Zejména v případě relativně nových fenoménů jako memes není lehké určit, zda užití původního díla je ospravedlněno výjimkou pro parodii nebo karikaturu či nikoli. Hranice mezi zákonem uznávanými a novými formami transformativního užití díla je tedy $\mathrm{v}$ dnešní době poměrně tenká.

Co do právního rámce obsahu vytvářeného uživateli, $v$ některých případech bude požívat ochrany poskytované systémem výjimek a omezení au-

WONG, Mary W. S. „Transformative" User-Generated Content in Copyright Law: Infringing Derivative Works or Fair Use? Vanderbilt Journal of Entertainment \& Technology Law. 2009, roč. 11, č. 4. s. $1077-1079$.

8 OECD, Graham VICKERY a Sacha WUNSCH-VINCENT. Participative Web and User-Created Content [online]. 2007. s. 18. [cit. 26.09.2020]. Dostupné z: https://www.oecd-ilibrary.org/content/publication/9789264037472-en

9 Pro další definice viz např. https://www.merriam-webster.com/dictionary/meme nebo https://dictionary.cambridge.org/dictionary/english/meme. 
torského práva. Tyto výjimky a omezení byly z různých důvodů společností uznány jako prospěšné a hodné ochrany (přispívají např. k zachování kulturní rozmanitosti, rozvoji vědy nebo uplatňování svobody projevu). Vycházejí ze základních práv a svobod zakotvených mj. v Listině základních práv Evropské Unie (dále jen“LZPEU“), ve většině případů ze svobody umění a věd dle článku 13. Některé výjimky jako parodie nebo karikatura mají rovněž silný politický podtext a jsou proto úžeji spjaty se svobodou projevu a informací zaručenou článkem 11 LZPEU.

Na evropské úrovni jsou výjimky a omezení autorského práva upraveny zejména ve článku 5 InfoSoc směrnice ${ }^{10}$ obsahujícím výčet výjimek a omezení, které členské státy mohou, ale nemusejí, implementovat. Aby mohly být využívány, musejí výjimky v každém konkrétním případě projít tzv. třístupňovým testem. Třistupňový test zahrnuje podmínky, které musí být splněny kumulativně. Za prvé lze výjimky a omezení uplatnit v určitých zvláštních případech. Za druhé, užití díla by nemělo být $\mathrm{v}$ rozporu $s$ běžným zpưsobem užití díla. Za třetí, užitím díla nesmějí být nepřiměřeně dotčeny oprávněné zájmy autora.

Jiná transformativní užití této ochrany nepožívají. Důvodem může být skutečnost, že jsou relativně nová, takže zatím nebyla reflektována v právní úpravě. Zejména užití, která vykazují vysokou míru kreativity a transformace původního obsahu a jsou společensky prospěšná, mají teoretické předpoklady se stát součástí evropského systému výjimek a omezení, nicméně problém $\mathrm{s}$ jejich zakotvením $\mathrm{v}$ InfoSoc směrnici spočívá $\mathrm{v}$ tom, že katalog výjimek a omezení ve článku 5 InfoSoc směrnice je taxativní a, byt’ toto je poněkud zjednodušující tvrzení, evropské autorské právo dosud spočívalo na širokém výkladu výlučných práv autora a restriktivní interpretaci výjimek a omezení autorského práva. ${ }^{11}$

10 Směrnice Evropského parlamentu a Rady 2001/29/ES ze dne 22. května 2001 o harmonizaci určitých aspektů autorského práva a práv s ním souvisejících v informační společnosti.

11 Např. rozsudek SDEU (čvrtého senátu) ze dne 16. 7. 2009 ve věci C-5/08, Infopaq, body 5657, rozsudek SDEU (třetího senátu) ze dne 21. 10. 2010 ve věci C-467/08, Padawan, bod 36, rozsudek SDEU (tř̌etího senátu) ze dne 26. 4. 2012 ve věci C 510/10, DR a TV 2 Denmark, bod 36 , Rozsudek SDEU (čtvrtého senátu) ze dne 10. 4. 2014 ve věci C 435/12, ACI Adam, body 33 - 34 . 
Nicméně probíhá normativní diskuze o významu UCG pro svobodu projevu. $^{12}$ Obsah vytvářený uživateli se stal nástrojem názorového sebevyjádření jednotlivců, kteří se z pasivních konzumentů mění v aktivní tvůrce a účastníky společenské diskuze. V USA zaznívají názory, že UGC má přímou vazbu na svobodu projevu zakotvenou v Prvním dodatku, protože naplňuje účel této svobody, kterým je rozvoj demokratické participativní kultury. ${ }^{13}$ Jako př́klad lze uvést videa vytvářená na podporu určité politické kampaně, pomocí kterých mohou jednotlivci obeznámit se svým názorem širokou veřejnost. Proto je třeba přizpůsobit koncepci svobody projevu novým poměrům a zejména zabránit tomu, aby práva duševního vlastnictví působila jako překážka pro šíření kulturních fenoménů. ${ }^{14}$

Stř̌et svobody projevu a práva duševního vlastnictví se také promítnul do rozsudků Evropského soudu pro lidská práva ve věcech Ashby Donald proti Francii ${ }^{15}$ a Neij proti Švédsku. ${ }^{16} \mathrm{~V}$ těchto rozsudcích ESLP vyjádřil myšlenku, že svoboda projevu je výchozím bodem, od kterého se právo duševního vlastnictví odchyluje. ${ }^{17} \mathrm{Na}$ rozdíl od tradičního pojetí práva duševního vlastnictví ESLP chápe svobodu projevu jako vnější limit práva autorského a práv souvisejících, který je schopen ospravedlnit užití děl, která porušují tato práva. ${ }^{18}$

12 Pro detailní přehled viz LEE, Yin Harn. Copyright and Freedom of Expression: A Literature Review [online]. CREATe, 2015. s. 119 an. [cit. 24.09.2020]. Dostupné z: DOI:10.5281/ zenodo.18132

${ }^{13}$ BALKIN, Jack. Digital speech and democratic culture: A theory of freedom of expression for the information society. New York University Law Review. 2004, roč. 79. s. 33 -38.

14 Ibid. s. 53.

${ }^{15}$ Rozsudek ESLP ze dne 10. 1. 2013 ve věci Ashby Donald a dalš́ proti Francii, stížnost č. 36769/08.

${ }^{16}$ Rozsudek ESLP ze dne 19. 2. 2013 ve věci Neij a Sunde Kolmisoppi proti Švédsku, stížnost č. 40397/12.

${ }^{17}$ GEIGER, Christophe a Elena IZYUMENKO. Copyright on the Human Rights' Trial: Redefining the Boundaries of Exclusivity Through Freedom of Expression. IIC - International Review of Intellectual Property and Competition Law. 2014, roč. 45. s. 325.

${ }^{18}$ QUINTAIS, João. Copyright in the Age of Online Access: Alternative Compensation Systems in EU Law. Wolters Kluwer, 2017. s. 255. 


\section{3. ČLÁNEK 17 DSM SMĚRNICE: KONEC BEZPEČNÉHO PŘÍSTAVU}

Jak již bylo zmíněno v úvodu, DSM směrnice mění právní status YouTube. Článek 2 odst. 6 DSM směrnice zavádí novou kategorii poskytovatele služeb pro sdílení obsahu online (dále jen „poskytovatel“), jímž je míněn poskytovatel služby informační společnosti, jehož hlavním účelem nebo jedním z hlavních účelů je uchovávat velký počet děl chráněných autorským právem nebo jiných předmětů ochrany nahrávaných jeho uživateli a zpř́istupňovat je veřejnosti, přičemž poskytovatel tato díla a jiné předměty ochrany uspořádává a propaguje za účelem zisku. Z této definice jsou vyňaty některé subjekty jako např. neziskové online encyklopedie, nezisková vzdělávací a vědecká úložiště, platformy pro vývoj a sdílení softwaru s otevřeným zdrojovým kódem.

Podle odstavce 1 článku 17 DSM směrnice poskytovatelé provádějí sdělení veřejnosti nebo zpřístupnění veřejnosti pro účely této směrnice, pokud poskytují veřejnosti přístup $\mathrm{k}$ dílům chráněným autorským právem nebo jiným předmětům ochrany nahraným svými uživateli. Podle odstavce 3 článku 17 DSM směrnice se v takovém případě na poskytovatele nevztahuje omezení odpovědnosti podle článku 14 odst. 1 EC směrnice. ${ }^{19}$ Článek 17 DSM směrnice tedy zakotvuje primární odpovědnost poskytovatele za obsah nahrávaný uživateli.

\section{DVĚ CESTY IMPLEMENTACE}

Článek 17 DSM směrnice dává poskytovatelům dvě možnosti, jak předejít odpovědnosti za sdílení uživatelského obsahu. První možností zakotvenou v odstavcích 1 a 2 článku 17 DSM směrnice je získání svolení nositelů práv, které se rovněž bude automaticky vztahovat i na nekomerční aktivity uživatelů. Druhou možností obsaženou v odstavci 4 článku 17 DSM směrnice je prokázat, že poskytovatel „vynaložil veškeré úsilí k získání svolení“ a že „ v souladu s vysokými odvětvovými standardy odborné péče vynaložil veškeré úsilí k zajištění nedostupnosti děl [...], o nichž mu nositelé práv po-

19 Směrnice Evropského parlamentu a Rady 2000/31/ES ze dne 8. června 2000 o některých právních aspektech služeb informační společnosti, zejména elektronického obchodu, na vnitřním trhu (směrnice o elektronickém obchodu). 
skytli relevantní informace“. V prŕpadě oznámení nositelů práv o obsahu porušujícím jejich práva se aktivuje notice and takedown mechanismus nejspíše inspirovaný článkem 512 Digital Millenium Copyright Act.

Ačkoli odstavec 8 článku 17 DSM směrnice stanovuje, že uplatňování článku 17 nesmí vést $\mathrm{k}$ žádným povinnostem v oblasti dohledu, a navzdory moderačnímu pravidlu zakotvenému v odstavci 5 článku 17 DSM směrnice, druhá možnost zjevně vede $\mathrm{k}$ uplatňování systémů automatizovaného rozpoznávání obsahu. Pro tento závěr svědčí objem obsahu nahrávaného uživateli - jak už bylo zmíněno výše, v březnu 2019 bylo každou minutu na YouTube nahráváno cca 500 hodin videa. Evropská komise sice ve svém konzultačním dokumentu uvádí, že členské státy by při implementaci neměly podmínit prokazování „vynaložení veškerého úsilí“ ze strany poskytovatelů nasazením určité technologie, ${ }^{20}$ není však jasné, jakým způsobem by jinak měli poskytovatelé dostát svým povinnostem podle odstavce 4 článku 17 DSM směrnice.

\section{CONTENT ID}

\subsection{CONTENT ID JAKO STANDARD}

Google s oblibou představuje ContentID jako jeden z nejdokonalejších nástrojů svého druhu, což není překvapivé, uvážíme-li, že do vývoje Content ID bylo investováno přes 90 milionů dolarů. ${ }^{21}$ Databáze Content ID obsahuje přes 80 milionů referenčních souborů. ${ }^{22}$ Jak poznamenává Tóth, za účelem efektivního zajištění nedostupnosti chráněných děl budou mít poskytovatelé zájem o nasazení nejmodernějších preventivních technologií. ${ }^{23}$ Přihlédneme-li zároveň ke znění odstavce 4 článku 17 DSM směrnice, který

20 Targeted consultation addressed to the participants to the stakeholder dialogue on Article 17 of the Directive on Copyright in the Digital Single Market [online]. Evropská komise, [cit. 24.09.2020]. Dostupné z: https://ec.europa.eu/eusurvey/runner/4fd43123-6008a214-f572-4ecd331b9e0e

${ }^{21}$ Öffentliche Konsultation zur Umsetzung der EU-Richtlinie imUrheberrecht (DSM-RL (EU) 2019/790). op. cit.

${ }^{22}$ How Google Fights Piracy. op. cit. s. 14.

${ }^{23}$ TÓTH, Andrea. Algorithmic Copyright Enforcement and AI: Issues and Potential Solutions through the Lens of Text and Data Mining. Masaryk University Journal of Law and Technology. 2019, roč. 13. s. 376. 
vyžaduje soulad $s$,vysokými odvětvovými standardy odborné péče“, se tedy dá předpokládat, že Content ID a podobné systémy automatického rozpoznávání obsahu budou pro vytyčení těchto standardů určující. Z tohoto důvodu je nyní namístě tento systém stručně představit a na jeho př́́kladu rovněž prozkoumat nevýhody systémů automatického rozpoznávání obsahu zejména ve vztahu k uživatelům tvořícím obsah.

Princip Content ID je takový, že videa nahraná na YouTube jsou porovnávána s databází referenčních souborů poskytnutých nositeli autorských práv. Databáze systému Content ID obsahuje více než 80 milionů referenčních souborů, což z ní činí největší databázi na světě. Content ID využívá technologie fingerprinting. Tato technologie zkoumá vlastnosti samotného média (např. noty u zvukového záznamu) místo toho, aby zkoumala a porovnávala bity souboru, do kterého je obsah zakódován. Fingerprint konkrétního zvukového záznamu tedy bude obsahovat takové informace jako intenzita různých frekvencí v určitém časovém intervalu. Vzhledem k tomu, že fingerprinting využívá algoritmů, které zpracovávají charakteristiky média obsaženého v souboru (např. sled frekvencí ve skladbě), je omezen na konkrétní typ obsahu a je nutné mít odlišné nástroje pro videa, zvukové záznamy a další typy médiii. ${ }^{24}$

Po uplatnění nároku $\mathrm{k}$ videu má nositel práv tř̌i možnosti: dostávat př́ijmy z reklam videa, ponechat video prrístupným a sledovat statistiku prohlížení nebo zablokovat video na YouTube úplně. YouTube poté uplatní u tohoto obsahu preferovanou akci nositele práv. Nicméně nejčastějším scénářem je zpeněžení. $\mathrm{V}$ roce 2017 se nositelé práv rozhodli zpeněžit $90 \%$ všech nároků v systému Content ID. V hudebním průmyslu se nositelé práv rozhodli zpeněžit více než $95 \%$ nároků na ID obsahu. Během posledních 5 let vyplatil YouTube nositelům práv využívajícím Content ID více než 3 miliardy dolarů. ${ }^{25}$

\footnotetext{
${ }^{24}$ ENGSTROM, Evan a Nick FEAMSTER. The Limits of Filtering [online]. Engine, 2017. s. 13 15. [cit. 28.05.2020]. Dostupné z: https://www.engine.is/the-limits-of-filtering

${ }^{25}$ How Google Fights Piracy. op. cit. s. 13.
} 


\section{2 ÚSKALÍ CONTENT ID}

I přes soustavné zdokonalování a značné investice vykazuje Content ID určité nedostatky. Některé mají přičcinu v současném stavu technologického rozvoje, jiné plynou z povahy systémů automatizovaného rozpoznávání obsahu. Hlavní potíží je skutečnost, že Content ID z principu nerozlišuje účel, za jakým došlo $\mathrm{k}$ užití cizího díla. Content ID umožňuje nositelům práv $\mathrm{k}$ autorskému dílu automaticky identifikovat, jestli jsou ve videu použity prvky, které jsou totožné s jejich obsahem. Na základě této identifikace následně dojde ke vznesení nároku. To, že systém správně určí shodu, však samo o sobě neznamená, že jde o neoprávněné užití. Během dialogu Komise a zúčastněných stran na základě odstavce 10 článku 17 DSM směrnice bylo zástupci šesti poskytovatelů systémů automatizovaného rozpoznávání obsahu potvrzeno, že jejich systémy nedokážou zohlednit kontext, ve kterém dochází $\mathrm{k}$ užití, a jako takové nemohou stanovit, zda užití spadá do rámce výjimky nebo omezení či nikoli. ${ }^{26}$ Nadto se určité množství obsahu vytvořeného uživateli pohybuje na hraně zákonem uznávaných výjimek a omezení a automatizovaný filtrovací systém není způsobilý rozlišovat jemné nuance. Tak např́klad k rozpoznání, že se jedná o parodii, zejména takovou, která není ostentativní, ale je vystavěna na rafinovaném smyslu pro humor, je potřeba humoru rozumět. Poněkud znepokojující je v tomto ohledu myšlenka, že když i zástupci poskytovatelů nejpoužívanějších systémů na trhu vyjadřují pochybnosti ohledně rozlišovacích schopností svých systémů, což teprve nástroje menších a méně významných poskytovatelů, kteří navíc v souladu s uplatňováním zásady přiměřenosti dle odstavce 5 článku 17 DSM směrnice zřejmě nemusejí prokazovat tak striktní dodržování „vysokých standardů odvětvové péče“?

Dalším úskalím, u kterého je však naděje, že je odstranitelné v čase, je poměrně velké množství neoprávněně vznesených nároků. Neoprávněnost má původ jak v technické nepřesnosti samotného systému automatizované-

${ }^{26}$ KELLER, Paul. Article 17 stakeholder dialogue: What we have learned so far - Part 1 Kluwer Copyright Blog. In: Kluwer Copyright Blog [online]. 2020 [cit. 28.05.2020]. Dostupné z: http://copyrightblog.kluweriplaw.com/2020/01/13/article-17-stakeholderdialogue-what-we-have-learned-so-far-part-1/? doing_wp_cron $=1590693562.1587688922882080078125$ 
ho rozpoznávání obsahu, ${ }^{27}$ tak v ne vždy efektivním odhalení podvodných, neopodstatněných či excesivních nároků. Dle YouTube je 99,7 \% Content ID nároků technicky správných, tedy nárokovaný obsah skutečně vykazuje shodu s referenčními soubory v databázi Content ID. ${ }^{28}$ Nicméně podle empirických studií je př́tomnost žadatelů o stažení obsahu ve zlé viŕre motivovaných například obtěžováním konkurence, umlčením kritiků či poškozením dobré pověsti poskytovatele nezanedbatelná. ${ }^{29}$

Následující skupina problémů se týká znevýhodnění uživatelů-jednotlivců, kteří na YouTube sdílejí vlastní obsah. Jedním problémem je jednostranné určení osudu díla, které bylo shledáno porušujícím, ze strany YouTube a nositelů práv. Byṫ obecně lze monetizaci obsahu považovat za kladnou stránku Content ID, protože takovým způsobem je přístup k obsahu zachován, je monetizace problematická z toho důvodu, že funguje jako zpětné udělování licence $\mathrm{k}$ užití autorskoprávně chráněného obsahu. Jednak takovou možnost licencování evropské právo vůbec nepředvídá, jednak jsou podmínky takové licenční smlouvy diktovány nositeli práv a uživatel nemá možnost namítat jejich nepřiměřenost nebo vůbec nějak o nich jednat. ${ }^{30}$

Další skutečností, která může posílit obavy o zachování dostupnosti uživatelského obsahu, je překvapivý výsledek využití Content ID nositeli práv, kdy podle výsledků empirických studií přistupovali britští nositelé práv k odstraňování napadených videí na YouTube v rozporu s argumenty, které namítali proti zavedení výjimky z autorského práva ve prospěch uživatelů. ${ }^{31}$ Deklarované obavy se týkaly zachování ochrany tržní hodnoty děl, ohrožení integrity původního díla uživatelským obsahem apod. Ze studie však vyplynulo, že nositelé práv nechávali smazat obsah, který nebyl

\footnotetext{
URBAN, Jennifer M., Joe KARAGANIS a Brianna L. SCHOFIELD. Notice and takedown: Online service provider and rightsholder accounts of everyday practice. Journal of the Copyright Society of the USA. 2017, roč. 64, č. 3. s. 392.

${ }^{28}$ How Google Fights Piracy. op. cit. s. 25.

${ }^{29}$ URBAN, Jennifer M., Joe KARAGANIS a Brianna L. SCHOFIELD. Notice and takedown: Online service provider and rightsholder accounts of everyday practice. op. cit. s. 396.

${ }^{30}$ TÓTH, Andrea. Algorithmic Copyright Enforcement and AI: Issues and Potential Solutions through the Lens of Text and Data Mining. s. 376.

31 V daném př́ípadě šlo o zavedení výjimky pro účely parodie.
} 
populární a tudíž ani komerčně významný, což mohlo poškodit zejména uživatele-jednotlivce, a ponechávali dostupnými a zpeněžovali virální videa. ${ }^{32}$

Uživatele by mohla také poškozovat skutečnost, že uplatnění systémů automatizovaného rozpoznávání obsahu $\mathrm{k}$ vymáhání práv nositelů mění výchozí nastavení - jestliže dřive byl chráněný obsah dostupný, dokud nebylo shledáno, že porušuje práva nositelů, je nyní běžně obsah odstraněn, ledaže by byl schválen nositelem práv. ${ }^{33}$ Zejména ve světle nového pojetí odpovědnosti poskytovatele zaváděného článkem 17 DSM směrnice hrozí, že poskytovatelé budou inklinovat k blokování obsahu, aby naplnili pojem vynaložení „veškerého úsilí“. Zárukou proti overblockingu by měl být odstavec 7 článku 17 DSM směrnice, který proklamuje, že spolupráce mezi poskytovateli služeb pro sdílení obsahu online a nositeli práv nesmí vést k omezování dostupnosti děl nahraných uživateli, na která se vztahuje výjimka nebo omezení včetně výjimky pro parodii. Vzhledem $\mathrm{k}$ tomu, že toto prohlášení není doprovázeno žádnými konkrétními opatřeními na omezení excesivní cenzury obsahu, zdá se, že poskytovatelé postrádají motivaci znepř́stupňovat obsah selektivně a $\mathrm{k}$ overblockingu docházet bude. ${ }^{34}$

Ačkoli Content ID je využíván dobrovolně, $\mathrm{v}$ obecné rovině je zavádění systémů automatizovaného rozpoznávání obsahu problematické také z důvodů rozporu takové povinnosti se základními právy. Nesoulad uložení obecné monitorovací povinnosti poskytovateli služeb informační společnosti s jeho právem na podnikání a s právy uživatelů na respektování soukromí a na ochranu osobních údajů už byl reflektován v judikatuře

${ }^{32}$ ERICKSON, Kristofer a M KRETSCHMER. „This Video is Unavailable": Analyzing Copyright Takedown of User-Generated Content on YouTube. JIPITEC : Journal of Intellectual Property, Information Technology and E-Commerce Law. 2018, roč. 9. s. 21 - 24.

33 ELKIN-KOREN, Niva. Fair Use by Design. UCLA Law Review [online]. 2017, roč. 64, č. 22. s. 1082. [cit. 24.09.2020]. Dostupné z: https://ssrn.com/abstract $=3217839$

34 SENFTLEBEN, Martin. Bermuda Triangle - Licensing, Filtering and Privileging User-Generated Content Under the New Directive on Copyright in the Digital Single Market ". SSRN Electronic Journal. 2018. s. 8. 
Soudního dvora Evropské unie. ${ }^{35} \mathrm{~V}$ rozsudku $\mathrm{SABAM}^{36}$ se kolektivní správce domáhal uložení povinnosti filtrování obsahu společnosti Netlog, která na svých stránkách umožňovala uživatelům sdílení hudby, filmů, fotografií a dalšího obsahu. Díla, k nimž spravoval práva SABAM, měla být znepřístupněna. Soudní dvůr Evropské unie seznal, že uložení takové časově neomezené povinnosti $\mathrm{v}$ oblasti dohledu by výrazně zasáhlo do svobody podnikání společnosti Netlog a do svobody projevu a informací uživatelů platformy Netlog. ${ }^{37}$ Pokud by se však plnění povinností uložených článkem 17 DSM směrnice prostřednictvím Content ID stalo „vysokým odvětvovým standardem odborné péče“, ostatní poskytovatelé by byli touto okolností nuceni k zavedení podobných systémů.

\section{DRUHÁ CESTA}

Vzhledem $\mathrm{k}$ výše diskutované problematičnosti systémů automatizovaného rozpoznávání obsahu se zdá být vhodnější cesta získání svolení nositelů práv. Tato možnost má také určité nevýhody. Jádrem těchto problémů je otázka, jak efektivně získat svolení nositelů práv pro tak veliké množství děl. První možností, kterou přímo nabízí alinea 2 odstavce 1 článku 17 DSM směrnice, je uzavření licenční smlouvy. Status quo pro většinu online užití děl je individuální výkon výlučných práv. ${ }^{38} \mathrm{~S}$ výjimkou licencí typu creative commons je získávání takových licencí náročné a nákladné a navíc $s$ ohledem na množství licencí, které je třeba získat, těžko uskutečnitelné.

Nabízí se tedy tzv. systémy náhradních odměn (alternative compensation systems), jejichž podstatou je, že dávají přednost zpřístupnění díla za přiměřenou odměnu před tradičním modelem výlučného výkonu práv a jejich vymáhání v případě porušení. ${ }^{39}$ Zahrnují dobrovolnou, rozšířenou a povinnou

35 Viz např. rozsudek SDEU (tř̌etího senátu) ze dne 24. 11. 2011 ve věci C-70/10, Scarlet Extended a rozsudek SDEU (čtvrtého senátu) ze dne 27. 3. 2014 ve věci C-314/12, UPC Telekabel.

${ }^{36}$ Rozsudek SDEU (třetího senátu) ze dne 16. 2. 2012 ve věci C-360/10, SABAM.

${ }^{37}$ Ibid. body $46-50$.

${ }^{38}$ QUINTAIS, João. Copyright in the Age of Online Access: Alternative Compensation Systems in EU Law. s. 87.

39 Ibid. 
kolektivní správu a zákonné licence. S ohledem na obšírnost tématu kolektivní správy se tento příspěvek dále zaměří zejména na možnost zavedení zákonných licencí.

\section{PŘEDPOKLADY PRO ZAVEDENÍ ZÁKONNÉ LICENCE}

Při řešení problému získání svolení nositelů práv přichází v úvahu také zavedení nové zákonné licence, která by v souladu s recitálem 74 DSM směrnice měla být úplatná. Tato možnost ovšem předpokládá, že článek 17 DSM směrnice poskytuje členským státům dostatečný manévrovací prostor při implementaci směrnice, protože v dosavadní úpravě článku 5 InfoSoc směrnice byl výčet výjimek a omezení taxativní, jak už bylo zmíněno. Kromě toho výjimky a omezení dle InfoSoc směrnice musí splňovat podmínky tříkrokového testu. Pokud by však článek 17 DSM směrnice nepodléhal režimu InfoSoc směrnice, nevztahovala by se na něj ani tato omezení.

Není tedy překvapující, že vztah článku 17 DSM směrnice a režimu InfoSoc směrnice se stal předmětem akademické debaty. ${ }^{40}$ Šlo o to, zda právo na „sdělení veřejnosti nebo zpř́ístupnění veřejnosti pro účely této směrnice“ v odstavci 1 článku 17 DSM směrnice je právem na sdělování veřejnosti ve smyslu článku 3 InfoSoc směrnice nebo zda je vůči němu ve vztahu speciality, či snad jde o právo sui generis. Již zmiňovaný konzultační dokument Evropské komise postavil najisto, že článek 17 DSM směrnice je lex specialis ke článku 3 InfoSoc směrnice. ${ }^{41}$ Ve prospěch tohoto závěru svědčí jedinečná regulační technika článku 17 DSM směrnice, která místo přiznání výlučného práva nositeli práv (jako to dělá InfoSoc směrnice) stanovuje, že poskytovatel potřebuje svolení nositele práv, protože jinak zasahuje do práva nositele, a koncipuje složitý mechanismus odpovědnosti poskytovatele spolu

${ }^{40}$ HUSOVEC, Martin a João QUINTAIS. How to License Article 17? Exploring the Implementation Options for the New EU Rules on Content-Sharing Platforms. SSRN Electronic Journal. 2019.; Art. 17 DSMCD: a class of its own? How to implement Art. 17 into the existing national copyright acts, including a comment on the recent German Discussion Draft Part 1. In: Kluwer Copyright Blog [online]. 16. 7. 2020 [cit. 25.09.2020]. Dostupné z: http://copyrightblog.kluweriplaw.com/2020/07/16/art-17-dsmcd-a-class-of-its-own-howto-implement-art-17-into-the-existing-national-copyright-acts-including-a-comment-on-therecent-german-discussion-draft-part-1/

${ }^{41}$ Targeted consultation addressed to the participants to the stakeholder dialogue on Article 17 of the Directive on Copyright in the Digital Single Market. op. cit. s. 4. 
se stížnostním mechanismem uživatelů. Takovou úpravu nezná ani světové, ani evropské právo autorské. ${ }^{42}$ Rovněž jazykovým výkladem odstavce 1 článku 17 DSM směrnice, který stanoví, že poskytovatelé provádějí sdělení veřejnosti nebo zpř́stupnění veřejnosti „pro účely této směrnice“, lze dospět $\mathrm{k}$ tomu, že režim článku 17 DSM směrnice stojí stranou systému InfoSoc směrnice. Vzhledem k tomu, že je článek 17 DSM směrnice lex specialis, neplatí pro něj numerus clausus výjimek a omezení stanovený článkem 5 InfoSoc směrnice. Tímto jsou tedy, zdá se, otevřeny dveře pro různá jiná řešení než licenční smlouva.

\section{DER DEUTSCHE WEG}

Německé Spolkové ministerstvo spravedlnosti a ochrany spotřebitele zveřejnilo 24. června 2020 návrh druhého zákona $\mathrm{k}$ přizpůsobení autorského práva digitálnímu vnitřnímu trhu. Tento návrh počítá s přijetím nového zákona o autorskoprávní odpovědnosti poskytovatelů služeb pro sdílení obsahu online (Gesetz über die urheberrechtliche Verantwortlichkeit von Diensteanbietern für das Teilen von Online-Inhalten, dále jen „UrhDaG“). § 6 UrhDaG zavádí novou výjimku z autorského práva pro „mechanicky přezkoumatelná zákonem povolená užití‘ “43:

(1) Je př́pustné sdělování veřejnosti a pro tento účel potřebné rozmnožování autorskoprávně chráněných děl a částí děl pro nekomerční účely v následujícím rozsahu:

1. až 20 sekund téhož filmu nebo pohyblivé obrazové sekvence,

2. až 20 sekund téhož zvukového záznamu,

3. až 1000 znaků téhož textu,

4. fotografii nebo grafiku s objemem dat až $250 \mathrm{kB}$.

${ }^{42}$ Entwurf eines Zweiten Gesetzes zur Anpassung des Urheberrechts an die Erfordernisse des digitalen Binnenmarktes [online]. 2020. s. 34. [cit. 23.09.2020]. Dostupné z: https:// www.bmjv.de/SharedDocs/Gesetzgebungsverfahren/Dokumente/DiskE_II_Anpassung \%20Urheberrecht_digitaler_Binnenmarkt.pdf?_blob $=$ publicationFile\&v $=2$

${ }^{43}$ UrhDaG rozlišuje užití, jejichž př́pustnost nelze posoudit prostřednictvím stávajících technických prostředků (protože zatím nejsou tak dokonalé) a užití, jejichž soulad s autorskými právy lze posoudit pomocí systémů automatizovaného rozpoznávání obsahu. 
(2) Odstavce 1 se použije, pokud neexistuje žádné smluvní užívací právo povolující užití dle odstavce 1 a pokud se nejedná o zákonem povolené užití podle $\S 5 .^{44}$

Podle $\S 7$ odstavce 2 UrhDaG je poskytovatel povinen poskytnout nositeli práv přiměřenou odměnu za užití podle $\S 6$ UrhDaG. Nová zákonná výjimka tedy naplňuje požadavek úplatnosti vyplývající z recitálu 74 DSM směrnice. § 9 UrhDaG v souladu s odstavcem 2 článku 17 DSM směrnice vztahuje svolení, které platí pro poskytovatele, na nekomerční úkony uživatelů.

Podle důvodové zprávy $\mathrm{k}$ UrhDaG je účelem této výjimky zohlednění soudobých obchodních praktik, kdy pro reklamní účely jsou bezúplatně zpřístupňovány např. úryvky knih nebo trailery, ${ }^{45}$ a také ochrana obsahu vytvořeného uživateli. ${ }^{46}$

\section{ZÁKONNÁ LICENCE PRO UCG?}

I přes svůj úzký záběr má německá výjimka význam - její zavedení je v důvodové zprávě podepřeno přesvědčivou argumentací, že zavádět další výjimky a omezení v režimu článku 17 DSM směrnice je v souladu s evropským právem. Ukazuje tedy cestu pro další výjimky v rámci speciálního režimu článku 17 DSM směrnice. Takovou výjimkou by mohla být celoevropská úplatná zákonná licence pro užití chráněných děl s cílem vytváření UGC splňující charakteristiky definované OECD (viz část 2 tohoto př́ispěvku), tedy zejména určitý stupeň kreativní transformace původního obsahu a vytvoření mimo rámec profesní aktivity (slovy DSM směrnice pokud uživatelé „nejednají v rámci podnikatelské činnosti a pokud jejich činnost nevytváří významné př́ijmy“). V souladu s odstavcem 2 článku 17 DSM by

${ }^{44} \S 5$ UrhDaG, který odkazuje na výjimky a omezení autorského práva zakotvené v německém autorském zákoně (Urheberrechtgesetz) a stanovuje, že je přípustné sdělování veřejnosti a rozmnožování autorskoprávně chráněných děl pro účely citace, karikatury, parodie a další účely zakotvené $v$ německém autorském zákoně. Nutno poznamenat, že výjimka pro parodii, karikaturu a pastiš bude do německého práva implementována teprve v souvislosti s přijetím DSM směrnice.

${ }^{45}$ Entwurf eines Zweiten Gesetzes zur Anpassung des Urheberrechts an die Erfordernisse des digitalen Binnenmarktes. op.cit. s. 88.

${ }^{46}$ Ibid. s. 2. 
povinnost vyplácet nositelům práv náhradní odměnu spočívala na poskytovateli.

Obecné výhody zákonné licence jako formy licencování nejlépe vyvstanou v kontrastu ke kolektivní správě, která je teritoriálně rozdrobená a v některých oblastech jako např. v audiovizi není pro online práva zavedena. Dobrovolná a do jisté míry i rozšířená kolektivní správa navíc trpí tím, že nositelé práv se mohou rozhodnout pro opt-out. Možnost zastřešující licence se tedy ve mnoha evropských státech zdá být neuskutečnitelná. ${ }^{47}$ Nicméně k tomu, aby bylo řešení navrhované odstavcem 2 článku 17 DSM směrnice efektivní, je tento zastřešující efekt licencování nezbytný. Navíc poskytovatelé nemohou předvídat, jaká díla uživatelé nahrají, a tudíž ani to, čí svolení by měla být získána.

Zákonná licence pro obsah vytvářený uživateli by také mohla pomoci docílit rovnováhy mezi právem duševního vlastnictví a svobodou projevu a informací, kterou uživatelé často realizují právě prostřednictvím svých aktivit na YouTube a podobných platformách. Zavedení této zákonné licence by zabránilo overblockingu hrozícímu zejména $\mathrm{v}$ důsledku uplatnění systémů automatizovaného rozpoznávání obsahu (viz část 5.2 tohoto př́spěvku) a dalším negativním důsledkům vymáhání autorských práv a práv souvisejících, které by mohly vést $\mathrm{k}$ erozi participativního webu. Zároveň by zákonná licence zohledňovala také zájmy nositelů práv, kterým by se dostalo spravedlivé náhradní odměny.

\section{ZÁVĚR}

Jak Senftleben výstižně definoval problém článku 17 DSM směrnice, jeho ustanovení dohromady vytvářejí neurčitý prostor podobný Bermudskému trojúhelníku, jehož stranami jsou licencování, filtrování a problematika uživatelského obsahu. Ačkoli jádro tohoto příspěvku se zabývalo důvody, proč místo používání systémů automatizovaného rozpoznávání obsahu bude zejména $\mathrm{z}$ hlediska uživatelů vhodnější se vydat cestou licencování, a následně teoretickými předpoklady vytvoření nové výjimky v rámci reži-

47 SENFTLEBEN, Martin. Bermuda Triangle - Licensing, Filtering and Privileging User-Generated Content Under the New Directive on Copyright in the Digital Single Market “. op. cit. s. 4. 
mu článku 17 DSM směrnice, doufejme, že ve výsledku byl (byt’ poněkud schematicky) nastíněn jeden $\mathrm{z}$ bezpečných směrů vyplutí z těchto temných vod.

\section{SEZNAM ZDROJŮ}

\subsection{LITERATURA}

[1] BALKIN, Jack. Digital speech and democratic culture: A theory of freedom of expression for the information society. New York University Law Review. 2004, roč. 79, s. 1-58.

[2] BURGESS, Jean a Joshua GREEN. YouTube: Online Video and Participatory Culture. 2. vyd. Polity Press, 2018. ISBN 978-0-7456-6019-6.

[3] ELKIN-KOREN, Niva. Fair Use by Design. UCLA Law Review [online]. 2017, roč. 64, č. 22 [cit. 24.09.2020]. Dostupné z: https://ssrn.com/abstract $=3217839$

[4] ENGSTROM, Evan a Nick FEAMSTER. The Limits of Filtering [online]. Engine, 2017 [cit. 28.05.2020]. Dostupné z: https://www.engine.is/the-limits-of-filtering

[5] ERICKSON, Kristofer a M KRETSCHMER. „This Video is Unavailable": Analyzing Copyright Takedown of User-Generated Content on YouTube. JIPITEC: Journal of Intellectual Property, Information Technology and E-Commerce Law. 2018, roč. 9

[6] GEIGER, Christophe a Elena IZYUMENKO. Copyright on the Human Rights' Trial: Redefining the Boundaries of Exclusivity Through Freedom of Expression. IIC - International Review of Intellectual Property and Competition Law. 2014, roč.45, s. 316-342.

[7] HUSOVEC, Martin a João QUINTAIS. How to License Article 17? Exploring the Implementation Options for the New EU Rules on Content-Sharing Platforms. SSRN Electronic Journal. 2019, s. 1-27.

[8] JOHNSON, Eric. Full Q\&A: YouTube CEO Susan Wojcicki talks about child safety, the Go ogle walkout, and AI on Recode Decode [online]. 2019 [cit. 27.09.2020]. Dostupné z: https://www.vox.com/podcasts/2019/3/11/18259303/youtube-susan-wojcicki-child-comments-videos-google-walkout-kara-swisher-decode-podcast-interview

[9] KELLER, Paul. Article 17 stakeholder dialogue: What we have learned so far - Part 1 Kluwer Copyright Blog. In: Kluwer Copyright Blog [online]. 2020 [cit. 28.05.2020]. Dostupné z: http://copyrightblog.kluweriplaw.com/2020/01/13/article-17-stakeholder-dialogue-whatwe-have-learned-so-far-part-1/?doing_wp_cron $=1590693562.1587688922882080078125$

[10] LEE, Yin Harn. Copyright and Freedom of Expression: A Literature Review [online]. CREATe, 2015 [cit. 24.09.2020]. Dostupné z: DOI:10.5281/zenodo.18132

[11] OECD, Graham VICKERY a Sacha WUNSCH-VINCENT. Participative Web and User-Created Content [online]. 2007 [cit. 26.09.2020]. Dostupné z: https://www.oecd-ilibrary.org/ content/publication/9789264037472-en 
[12] QUINTAIS, João. Copyright in the Age of Online Access: Alternative Compensation Systems in EU Law. Wolters Kluwer, 2017. ISBN 978-90-411-8667-6.

[13] SENFTLEBEN, Martin. Bermuda Triangle - Licensing, Filtering and Privileging UserGenerated Content Under the New Directive on Copyright in the Digital Single Market “. SSRN Electronic Journal. 2018, s. 1-18.

[14] TÓTH, Andrea. Algorithmic Copyright Enforcement and AI: Issues and Potential Solutions through the Lens of Text and Data Mining. Masaryk University Journal of Law and Technology. 2019, roč. 13, s. 361

[15] URBAN, Jennifer M., Joe KARAGANIS a Brianna L. SCHOFIELD. Notice and takedown: Online service provider and rightsholder accounts of everyday practice. Journal of the Copyright Society of the USA. 2017, roč. 64, č. 3, s. 317-410.

[16] WONG, Mary W. S. „Transformative" User-Generated Content in Copyright Law: Infringing Derivative Works or Fair Use? Vanderbilt Journal of Entertainment \& Technology Law. 2009, roč. 11 , č. 4, s. s. 1075-1139.

[17] Art. 17 DSMCD: a class of its own? How to implement Art. 17 into the existing national copyright acts, including a comment on the recent German Discussion Draft - Part 1. In: Kluwer Copyright Blog [online]. 16. 7. 2020 [cit. 25.09.2020]. Dostupné z: http://copyrightblog.kluweriplaw.com/2020/07/16/art-17-dsmcd-a-class-of-its-own-how-to-implement-art-17into-the-existing-national-copyright-acts-including-a-comment-on-the-recent-german-discussion-draft-part-1/

[18] Entwurf eines Zweiten Gesetzes zur Anpassung des Urheberrechts an die Erfordernisse des digitalen Binnenmarktes [online]. 2020. s. 34. [cit. 23.09.2020]. Dostupné z: https:// www.bmjv.de/SharedDocs/Gesetzgebungsverfahren/Dokumente/DiskE_II_Anpassung \%20Urheberrecht_digitaler_Binnenmarkt.pdf?_blob $=$ publicationFile\&v $=2$

[19] How Google Fights Piracy [online]. 2018 [cit. 24.09.2020]. Dostupné z: https:// www.blog.google/documents/27/How_Google_Fights_Piracy_2018.pdf

[20] Öffentliche Konsultation zur Umsetzung der EU-Richtlinie im Urheberrecht (DSM-RL (EU) 2019/790) [online]. Google a YouTube, 2019 [cit. 23.09.2020]. Dostupné z: https:// www.bmjv.de/SharedDocs/Gesetzgebungsverfahren/DE/Konsultation_Umsetzung_EU_Richtlinien_Urheberrecht.html?nn $=6712350$

[21] Targeted consultation addressed to the participants to the stakeholder dialogue on Article 17 of the Directive on Copyright in the Digital Single Market [online]. Evropská komise, [cit. 24.09.2020]. Dostupné z: https://ec.europa.eu/eusurvey/runner/4fd43123-6008-a214f572-4ecd331b9e0e

\subsection{JUDIKATURA}

[21] Rozsudek SDEU (čvrtého senátu) ze dne 16. 7. 2009 ve věci C-5/08, Infopaq, ECLI:EU:C:2009:465. 
[22] Rozsudek SDEU (třetího senátu) ze dne 21. 10. 2010 ve věci C-467/08, Padawan, ECLI:EU:C:2010:620.

[23] Rozsudek SDEU (tř̌etího senátu) ze dne 26. 4. 2012 ve věci C 510/10, DR a TV 2 Denmark, ECLI:EU:C:2012:244.

[24] Rozsudek SDEU (čtvrtého senátu) ze dne 10. 4. 2014 ve věci C 435/12, ACI Adam, ECLI:EU:C:2014:254.

[25] Rozsudek SDEU (tř̌etího senátu) ze dne 24. 11. 2011 ve věci C-70/10, Scarlet Extended, ECLI:EU:C:2011:771.

[26] Rozsudek SDEU (čtvrtého senátu) ze dne 27. 3. 2014 ve věci C-314/12, UPC Telekabel, ECLI:EU:C:2014:192.

[27] Rozsudek SDEU (třetího senátu) ze dne 16. 2. 2012 ve věci C-360/10, SABAM, ECLI: EU:C:2012:8.

[28] Rozsudek ESLP ze dne 10. 1. 2013 ve věci Ashby Donald a další proti Francii, stížnost č. $36769 / 08$.

[29] Rozsudek ESLP ze dne 19. 2. 2013 ve věci Neij a Sunde Kolmisoppi proti Švédsku, stížnost č. 40397/12.

Toto dîlo lze užít v souladu s licenčními podmínkami Creative Commons BY-SA 4.0 International (http://creativecommons.org/licenses/by-sa/4.0/legalcode). 